\title{
Adipokines as endocrine, paracrine, and autocrine factors in breast cancer risk and progression
}

\author{
Linda Vona-Davis and David P Rose
}

Department of Surgery \& Mary Babb Randolph Cancer Center, West Virginia University, PO Box 9238, Morgantown, West Virginia 26506, USA

(Requests for offprints should be addressed to L Vona-Davis; Email: Ivdavis@ hsc.wvu.edu)

\begin{abstract}
Adipokines (leptin, adiponectin, and hepatocyte growth factor (HGF)) secreted from adipose tissue have come to be recognized for their contribution to the mechanisms by which obesity and related metabolic disorders influence breast cancer risk. In this review, we discuss the direct and indirect effects of these protein factors on the biological and clinical aspects of breast cancer biology, and emphasize their distinctive modes of action through endocrine-, paracrine-, and autocrine-mediated pathways. The stimulatory effects of leptin on breast cancer growth were considered to occur primarily via activation of the estrogen receptor; however, new evidence suggests that leptin may be acting on downstream cell signaling pathways in both estrogendependent and -independent cell types. Another secretory adipokine, HGF, may act largely not only to promote tumor cell invasion, but also to enhance tumor growth indirectly by stimulating angiogenesis. In contrast, adiponectin, an endogenous insulin sensitizer, exerts a direct growthinhibitory effect on tumor cells by downregulating cell proliferation and upregulating apoptosis, and also inhibits tumor-related angiogenesis.
\end{abstract}

Endocrine-Related Cancer (2007) 14 189-206

\section{Introduction}

A proportion of breast cancers require the presence of estrogens for their growth and progression to an invasive and metastatic phenotype. This hormone dependence derives from the capacity to respond to endocrine signaling in which the estrogen is secreted from its production sites in the ovaries or adipose tissue and carried via the blood to the target tumor cells where it interacts with the specific estrogen receptors (ER). In premenopausal women, the need for estrogens acting in an endocrine manner in order to sustain tumor growth is illustrated by the regression of ER-positive breast cancers which occurs in response to treatment by bilateral oophorectomy (Jensen \& Jordan 2003).

After the menopause, aromatization of the C19 steroid androstenedione in adipose tissue is the source of the circulating estrone and estradiol, the endocrine activities of which are considered to be major contributors to obesity-related postmenopausal breast cancer risk and progression (Key et al. 2003). However, there is an alternative mode of estrogen action which applies to this situation: the dense layer of adipose tissue fibroblasts which forms the capsule surrounding a premalignant or cancerous breast lesion may possess particularly high levels of aromatase activity, and in consequence enhance estrogen biosynthesis, so that the local conditions favor estrogenic stimulation of breast cancer cells by a paracrine mechanism in which the steroid diffuses from its site of origin to interact with the ER of the nearby tumor cells (Bulun et al. 1994). In addition, some breast cancers themselves possess aromatase activity, and the production of estrogens by ER-positive breast cancers presents the opportunity for growth stimulation by an autocrine mechanism (reviewed by de Jong et al. 2001, Sasano et al. 2006).

There is an extensive literature in which the relationships between hormones and growth factors and breast cancer risk, stage at diagnosis, and prognosis have been investigated using assays of their concentrations in plasma or serum samples. Examples of the success of this approach are the 
Table 1 Production of adipokines by the individual components of adipose tissue

\begin{tabular}{|c|c|c|}
\hline Adipokine & Principal synthesizing cell type & Other cell sources \\
\hline Leptin & $\begin{array}{l}\text { Preadipocytes and adipocytes } \\
\text { Simons et al. (2005) }\end{array}$ & $\begin{array}{l}\text { Fibroblasts and keratinocytes Murad } \\
\text { et al. (2003) }\end{array}$ \\
\hline Adiponectin & $\begin{array}{l}\text { Mature adipocytes (Simons et al. 2005, } \\
\text { Korner et al. 2005) }\end{array}$ & None \\
\hline Tumor necrosis factor- $\alpha$ & Macrophages Weisberg et al. (2003) & $\begin{array}{l}\text { Preadipocytes and adipocytes Meng et al. } \\
\text { (2001) and Wang et al. (2005) }\end{array}$ \\
\hline Interleukin-6 & Macrophages (Weisberg et al. 2003) & $\begin{array}{l}\text { Stromal cells Crichton et al. (1996) } \\
\text { adipocytes Wang et al. (2005) }\end{array}$ \\
\hline Hepatic growth factor & Stromal cells Rehman et al. (2004) & Adipocytes Rahimi et al. (1994) \\
\hline Vascular endothelial growth factor + & Stromal cells Rehman et al. (2004) & Adipocytes Mick et al. (2002) \\
\hline HB-EGF & Adipocytes Matsumoto et al. (2002) & $\begin{array}{l}\text { Vascular smooth muscle cells Mick } \\
\text { et al. (2002) }\end{array}$ \\
\hline
\end{tabular}

+ , vascular endothelial growth factor release from stromal cells and adipocytes is of similar degree (Mick et al. 2002). HB-EGF, heparin-binding epidermal growth factor-like growth factor.

demonstration of a positive association between high plasma estrogens and total and biologically active estradiol concentrations and postmenopausal breast cancer risk (Toniolo et al. 1995), and a positive correlation between fasting serum insulin levels and breast cancer risk (Del Giudice et al. 1998, Hirose et al. 2003, Lawlor et al. 2004) and prognosis (Goodwin et al. 2002).

More recently, there has been considerable interest in the potential role of the adipokines, a group of proteins synthesized in adipose tissue, in the development of cancers for which obesity has been established as a risk factor: these include the endocrine-related cancers of the breast (Harvie et al. 2003, Stephenson \& Rose 2003, Rose et al. 2004) and endometrium (Petridou et al. 2002, 2003, Cymbaluk et al. 2007). The adipose tissue cells that produce the adipokines include the fat cells (adipocytes) and the stromal cells (fibroblasts) which have the potential for differentiation to mature adipocytes, and the macrophages that infiltrate the adipose cell mass, and do so to an increased degree in obesity (Table 1). These macrophages are an important source of tumor necrosis factor- $\alpha$ (TNF- $\alpha)$ and responsible for the significant increase in local TNF- $\alpha$ synthesis which occurs in obese individuals (Weisberg et al. 2003). Fain et al. (2004) found that with the exception of leptin and adiponectin over $90 \%$ of the adipokines released by adipose tissue cultured in vitro were produced by nonfat cells. In addition to exerting local biological effects, adipokines circulate in the plasma, where the concentrations of most, including leptin, TNF- $\alpha$, interleukin-6 (IL-6), hepatocyte growth factor (HGF), and heparin-binding epidermal growth factor-like growth factor (HB-EGF) are positively correlated with the body mass index (BMI); one exception is adiponectin, the relationship of which with the BMI is a negative one (reviewed by Rose et al. 2004).

Two adipokines in particular, leptin and adiponectin, have come to be recognized for their influence on breast cancer risk and tumor biology. Their physiological and pathological relationships are largely in opposition to each other, as are their biological effects on breast cancer cells (Table 2). The third adipokine, HGF or 'scatter factor', may have a positive effect on tumor growth as a result of its angiogenic properties, but it is recognized primarily for its capacity to promote cell invasion.

In this review, we will consider those adipokines, leptin, adiponectin, and HGF, which are currently

Table 2 Comparison of leptin and adiponectin: pathophysiological relationships and effects on breast cancer biology

\begin{tabular}{lll}
\hline & Leptin & Adiponectin \\
\hline Obesity & Plasma levels elevated & Plasma levels suppressed \\
Insulin activity & Reduced sensitivity & Reduced resistance \\
Type 2 diabetes & Promotes development & Reduces risk \\
Metabolic syndrome & Hyperleptinemia & Hypoadiponectinemia \\
Breast cancer risk & Plasma levels equivocal relationship & Increased risk with low plasma levels \\
Breast cancer cell growth & Mitogenic & Antimitogenic \\
Tumor cell apoptosis & Reduced & Enhanced \\
Tumor angiogenesis & Stimulated & Inhibited \\
\hline
\end{tabular}


recognized as contributing to breast cancer cell biology, notably with effects on tumor cell mitosis and apoptosis, invasive capacity and metastasis, and the associated process of tumor-mediated angiogenesis. Our emphasis will be on the relative significance of their roles as endocrine, paracrine, and autocrine agents with the postulate that only by studying the individual adipokines in each of these separate roles can a full understanding be achieved of their contribution to the biological and clinical aspects of breast cancer.

\section{Adipokines as circulating hormones in breast cancer \\ Leptin}

The identification of leptin as a product of the obese $(o b)$ gene (MacDougald et al. 1995) and the demonstration that its circulating concentrations correlate positively with the BMI were quickly followed by attempts to relate the levels of leptin in serum or plasma to breast cancer risk. These have produced conflicting results: at present, there are three published reports of case-control studies which found that relatively high serum leptin concentrations were associated with an increased risk of breast cancer (Tessitore et al. 2000, Han et al. 2005, Chen et al. 2006a), but another six of straightforward case-control design (Petridou et al. 2000, Ozet et al 2001, Coskun et al. 2003, Sauter et al. 2004, Miyoshi et al. 2006, Woo et al. 2006), and a seventh with a case-control nested within a prospective study (Stattin et al. 2004), all gave negative results (Table 3 ).

The study by Tessitore et al. (2000) involved only 23 patients and 103 controls and found that the plasma leptin concentrations were elevated in breast cancer and correlated positively with the plasma insulin, but not the BMI. There were corresponding elevations in leptin mRNA expression in adipose tissue. Han et al. (2005) assayed the serum leptin concentrations in 90 breast cancer patients, 40 women with benign breast disease, and 103 healthy controls. The menopausal status of these Chinese women was not described, but the mean values and the standard deviations of their ages indicate that they included both premenopausal and postmenopausal women in all three diagnostic categories. In addition to the hyperleptinemia, the breast cancer patients had elevated serum insulin and triglyceride levels and reductions in the serum high-density lipoprotein cholesterol, all features of the metabolic syndrome.

A carefully detailed study by Chen et al. (2006a) involved 100 newly diagnosed Taiwanese premenopausal and postmenopausal breast cancer patients who were studied after surgery, but before the institution of any form of adjuvant therapy, and 100 healthy control women. The serum leptin concentrations were not related to menopausal status and were significantly higher in the breast cancer group. It is of interest that hyperleptinemia occurred in these patients in the absence of obesity, which is an uncommon condition in the Taiwanese female population.

Stattin et al. (2004) studied a relatively large number of breast cancer cases and controls, all of whom were matched for age (Table 3). Their experimental design was unique in that it was the only one of the nine studies in which a case-control comparison was made which was nested in a large prospective study. In consequence, the plasma samples were collected prior to the diagnosis of breast cancer, at which point all of the women were beyond the menopause. The observed lack of an association between the plasma leptin levels and breast cancer risk was unaffected by adjustment for the BMI or plasma insulin.

Miyoshi et al. (2006) reported that in their casecontrol study, there was no association between the serum leptin levels and breast cancer risk, but that there was a correlation between the serum leptin levels and intratumoral leptin mRNA expression. However, they did not consider that the tumor leptin synthesis would be sufficient to account for the serum leptin concentrations; rather, the source was likely to be the much higher levels of leptin production in the corresponding adipose tissue samples as reflected in their leptin mRNA expression.

The study performed by Ozet et al. (2001) included 30 breast cancer patients who had been receiving tamoxifen and 20 who were not on antiestrogen therapy; only the tamoxifen-treated patients showed plasma leptin concentrations which were significantly higher than those of the control women. An elevation in the serum leptin levels of tamoxifen-treated postmenopausal breast cancer patients had been reported previously and was considered to represent the well-recognized estrogen-like systemic effects of the antiestrogen (Marttunen et al. 2000). However, in general, the patients included in Table 3 were investigated before the initiation of postsurgical treatment and a confounding effect of tamoxifen adjuvant therapy does not account for the observed discrepancies between the results of the individual studies.

Most of the studies summarized in Table 3, and discussed earlier, assayed the leptin concentrations in the serum of blood collected from fasting patients (Petridou et al. 2000, Ozet et al. 2001, Coskun et al. 2003, Sauter et al. 2004, Han et al. 2005, Chen et al. 2006a, Woo et al. 2006), but in two instances 
Table 3 Reports of plasma and serum leptin concentrations and breast cancer risk

\begin{tabular}{|c|c|c|c|c|}
\hline Reference & $\begin{array}{l}\text { Number of cases } \\
\text { Age of women }\end{array}$ & $\begin{array}{l}\text { Number of controls } \\
\text { Age of women }\end{array}$ & Menopausal status & Results \\
\hline $\begin{array}{l}\text { Tessitore et al. } \\
\quad(2000)\end{array}$ & $\begin{array}{l}23 \\
64.4 \pm 12.3\end{array}$ & $\begin{array}{l}103 \\
42.7 \pm 8.7\end{array}$ & $N A^{a}$ & $\begin{array}{l}\text { Plasma leptin higher in } \\
\text { breast cancer patients } \\
\text { than in controls }\end{array}$ \\
\hline Han et al. (2005) & $\begin{array}{l}90 \\
45.9 \pm 9.2\end{array}$ & $\begin{array}{l}103 \\
46.6 \pm 9.6\end{array}$ & $\begin{array}{l}\text { Serum leptin levels not } \\
\text { related to menopausal } \\
\text { status }\end{array}$ & $\begin{array}{l}\text { Serum leptin higher in } \\
\text { breast cancer than in } \\
\text { benign breast disease } \\
\text { or in healthy controls }\end{array}$ \\
\hline $\begin{array}{l}\text { Chen et al. } \\
\qquad(2006 a, b)\end{array}$ & $\begin{array}{l}100 \\
49.9 \pm 1.0\end{array}$ & $\begin{array}{l}100 \\
48.9 \pm 1.6\end{array}$ & $\begin{array}{l}\text { Pre- and postmenopausal } \\
\text { No significant effect of } \\
\text { age or menopausal } \\
\text { status on leptin }\end{array}$ & $\begin{array}{l}\text { Serum leptin higher in } \\
\text { breast cancer; } \\
P=0.025\end{array}$ \\
\hline $\begin{array}{l}\text { Petridou et al. } \\
\quad(2000)\end{array}$ & $\begin{array}{l}75 \\
<55(n=18) \\
>55(n=57)\end{array}$ & $\begin{array}{l}75 \\
<55(n=18) \\
>55(n=57)\end{array}$ & NA & $\begin{array}{l}\text { No association in postme } \\
\text { nopausal women } \\
\text { Significant inverse } \\
\text { association premeno- } \\
\text { pausally }\end{array}$ \\
\hline Ozet et al. (2001) & $\begin{array}{l}58 \\
\text { Pre }(n=15) 38.7 \pm 1.3 \\
\text { Post }(n=43) 56.7 \pm 1.2\end{array}$ & $\begin{array}{l}25 \\
51.8 \pm 1.2\end{array}$ & Pre- and postmenopausal & No association \\
\hline $\begin{array}{l}\text { Coskun et al. } \\
\text { (2003) }\end{array}$ & $\begin{array}{l}85 \\
\text { Remission }(n=55) 51.2 \pm 11.1 \\
\text { Metastatic }(n=30) 48.5 \pm 13.5\end{array}$ & $\begin{array}{l}25 \\
44.5 \pm 11.6\end{array}$ & NA & No association \\
\hline $\begin{array}{l}\text { Sauter et al. } \\
\quad(2004)\end{array}$ & $\begin{array}{l}28 \\
\text { Median } 47(23-81)\end{array}$ & $\begin{array}{l}54 \\
\text { Median } 47 \text { (23-81) }\end{array}$ & $\begin{array}{l}\text { Pre- and postmenopausal } \\
\text { No effect of menopausal } \\
\text { status on leptin levels }\end{array}$ & No association \\
\hline $\begin{array}{l}\text { Stattin et al. } \\
\quad(2004)\end{array}$ & $\begin{array}{l}149 \\
59.8(50.1-68.7)\end{array}$ & $\begin{array}{l}258 \\
60.1(50.1-68.8)\end{array}$ & Postmenopausal & No association \\
\hline Woo et al. (2006) & $\begin{array}{l}\text { Pre }(n=30), \text { Post }(n=30) \\
\quad<40(5), 40-60(33), \geq 60(7)\end{array}$ & $\begin{array}{l}45 \\
\text { Pre }(n=26), \text { Post }(n=19) \\
\quad<40(5), 40-60(33), \geq 60 \\
\quad(7)\end{array}$ & $\begin{array}{l}\text { Pre- and postmenopausal } \\
\text { No effect of menopausal } \\
\text { status on leptin levels }\end{array}$ & No association \\
\hline $\begin{array}{l}\text { Miyoshi et al. } \\
\quad(2006)\end{array}$ & $\begin{array}{l}104 \\
\text { NA }\end{array}$ & $\begin{array}{l}104 \\
\mathrm{NA}\end{array}$ & NA & No association \\
\hline
\end{tabular}

${ }^{\mathrm{a} N A}$, not available.

(Tessitore et al. 2000, Stattin et al. 2004), fasting plasma samples were used. Miyoshi et al. (2006) assayed serum, but did not state the fasting status of the patients. Whether the use of serum or plasma for leptin studies is of practical significance is unclear, but it has been reported that the concentrations determined are lower in sera, and have a greater coefficient of variation, than in the EDTA or lithium heparinateanticoagulated plasmas prepared from the same blood samples (Groschl et al. 2000).

The majority of the reported studies of circulating leptin concentrations in breast cancer involved only small groups of patients, and some included both premenopausal and postmenopausal women without subgroup analysis. This may have introduced hormone-related confounding factors because some investigators have reported that the leptin concentrations are higher in blood from premenopausal women than in postmenopausal women who are not receiving estrogen replacement therapy (Centro et al. 1999, Hayase et al. 2002). In premenopausal women, it may be necessary to take into account of the stage in the menstrual cycle at which the blood samples are collected, as the levels of leptin have been found to be higher in the late follicular and luteal phases of the normal cycle (Riad-Gabriel et al. 1998, Cella et al. 2000, Geisthovel et al. 2004).

Further studies of circulating leptin concentrations in relation to breast cancer risk are obviously needed, and in addition to including larger numbers of women, these should ideally be of prospective design. Consideration needs to be given to the possible presence of other common clinical conditions which are known to be associated with an increased breast cancer risk, such as type 2 diabetes and the metabolic syndrome (Rose et al. 2004), and which may also be associated with elevated serum leptin levels in the absence of obesity (Fischer et al. 2002, Franks et al. 2005). 
We reviewed elsewhere the biological actions of leptin which suggested that this adipokine would prove to be associated with aggressive breast cancers expressing an invasive/metastatic phenotype and having a poor prognosis (Rose et al. 2002). Later, Goodwin et al. (2005) evaluated plasma leptin levels as a prognostic indicator in breast cancer patients, but although they did observe an association between relatively high concentrations and both higher tumor stage and grade, and negative steroid hormone receptor status, recognized predictors of a poor prognosis, there was no clear-cut relationship to disease outcome in this patient population. In the study from Taiwan, Chen et al. (2006a) found no relationship between the serum leptin levels and either tumor grade or regional lymph node involvement, but the concentrations were positively correlated with tumor size. There is clearly a need for additional studies of this issue with larger numbers of patients.

\section{Adiponectin}

Adiponectin is present in serum as three molecular species: a trimer, a hexamer, and a high molecular weight isoform (Kobayashi et al. 2004). The biological functions of adiponectin and the individual isoforms are currently the subject of intense investigation, with emerging roles in both protection from the consequences of insulin resistance, and the modulation of endothelial function.

In contrast to leptin, the three reported epidemiological studies of adiponectin have all demonstrated an inverse association between the serum adiponectin levels and breast cancer risk (Miyoshi et al. 2003, Mantzoros et al. 2004, Chen et al. 2006a,b). One of these (Miyoshi et al. 2003) also found that low serum adiponectin concentrations were associated with large tumors and tumors of high histologic grade, a result consistent with hypoadiponectinemia being a marker of an aggressive phenotype; there was no relationship between the adiponectin levels and ER status. Serum adiponectin concentrations were also assayed in the study of Taiwanese women referred to earlier which was performed by Chen et al. (2006a). Here too, the adiponectin levels were significantly lower in the breast cancer patients when compared with the control women. As in the case of the leptin results obtained by these investigators, the serum adiponectin levels were not related to ER status, or to tumor grade or stage; however, there was a particularly strong positive correlation between the leptin:adiponectin ratio and tumor size.

\section{Hepatocyte growth factor (HGF)}

HGF is produced at multiple sites, but the demonstration that it is synthesized and secreted by both adipocytes and adipose stromal cells (Rahimi et al. 1994, Rehman et al. 2004, Bell et al. 2006) qualifies it as an adipokine. Moreover, in support of adipose tissue as a major source of circulating HGF, it was shown that serum HGF levels are elevated in obese women and men; there is a positive correlation between the serum HGH concentration and BMI (Rehman et al. 2003). In addition, there was a reduction in serum HGF after weight loss accompanied by a decrease in the secretion of this adipokine by isolated adipocytes (Bell et al. 2006).

Several investigations have shown that the serum concentrations of HGF are often elevated in breast cancer patients, and particularly so in those with advanced disease. Toi et al. (1998) reported that in a study of 200 breast cancer patients, high serum HGF levels were associated with large primary tumors and regional lymph node involvement, and in a multivariate analysis, the HGF concentration functioned as an independent prognostic indicator. These observations were consistent with those described by Sheen-Chen et al. (2005) who found that high preoperative serum HGF levels in 124 breast cancer patients, compared with 35 patients with benign breast disease, occurred particularly in those with ER-negative and poorly differentiated tumors and those with high-stage disease. Taniguchi et al. (1995) also found a relationship between preoperative serum HGF concentrations and disease stage, but what makes this study of particular interest is that the HGF levels were reduced after the removal of primary tumor, suggesting that a major portion of the circulating levels was produced by the tumor itself and/or the closely associated, and excised, adipose tissue.

\section{Adipokines as paracrine factors: ligand and receptor}

\section{Physiological functions}

Adipokines circulating in the blood can exert their biological actions on target cells by classical endocrine mechanisms, but in addition, like the inflammatory cytokines, they also operate at the local level through paracrine pathways (Fig. 1). For example, leptin enters the bloodstream from its principal site of production in the adipose tissue and as a circulating hormone is responsible for the regulation of energy balance through effects at the level of the hypothalamus (Blundell et al. 2001). However, it also performs as a paracrine factor in a number of its physiological activities, including its important role in normal 
placental function (Bajoria et al. 2002), its expression by myofibroblasts, keratinocytes, and s.c. adipocytes at sites of wound healing, where it contributes to the repair process by exerting paracrine stimulation of angiogenesis (Murad et al. 2003), and its local production in the anterior pituitary gland where it modulates thyrotropin secretion (Jin et al. 2000).

The physiological actions of adiponectin appear to be largely hormonal; for example, it acts as a circulating endocrine factor to enhance insulin sensitivity and protect against the risk of type 2 diabetes and inflammatory processes (Matsuzawa 2005). There are, however, physiological activities which are clearly paracrine in nature, such as the capacity of adipocytesecreted adiponectin to block leptin-induced production of TNF- $\alpha$ by macrophages (Zhao et al. 2005).

Adiponectin and leptin are both synthesized by adipocytes (Korner et al. 2005, Simons et al. 2005), and so may strictly be designated 'adipocytokines', a term which was applied more loosely by Funahashi et al. (1999) when they introduced it to include all of the growth factors and cytokines produced within the adipose tissue. Leptin, but not adiponectin, is also synthesized by preadipocytes and especially when these are stimulated in a paracrine manner by the pro-inflammatory cytokines, TNF- $\alpha$ and IL- $1 \beta$ (IL- $1 \beta$ ) which are themselves secreted by adipose tissueinfiltrating macrophages (Simons et al. 2005).
Adiponectin biosynthesis by adipocytes is downregulated in obesity and so the circulating concentrations are reduced (Kern et al. 2003). The mechanisms responsible for the downregulation are unclear, but in cell culture experiments, an unidentified component of serum was found to suppress adiponectin production, with serum from obese individuals having a somewhat greater effect (Korner et al. 2005). In other co-culture experiments, another paracrine loop between adipocytes and macrophages was demonstrated which this time resulted in the downregulation of adiponectin production, with the involvement of macrophage-secreted TNF- $\alpha$ (Suganami et al. 2005).

\section{Paracrine activity in breast cancer}

The structural and cellular features of the breast that favor the estrogenic stimulation of tumor cells by a paracrine mechanism also apply to the adipokines. Their production by the components of the adipose tissue and the infiltrating macrophages provides a microenvironment with opportunities for multiple and interactive paracrine activities between the tumor cells and the cellular components of local fat deposits.

Manabe et al. (2003) performed an instructive experiment which demonstrated the ability of adipose tissue to stimulate breast cancer growth by a paracrine mechanism. They used a three-dimensional collagen gel matrix co-culture technique to show that mature adipocytes secrete a factor(s) which can promote the

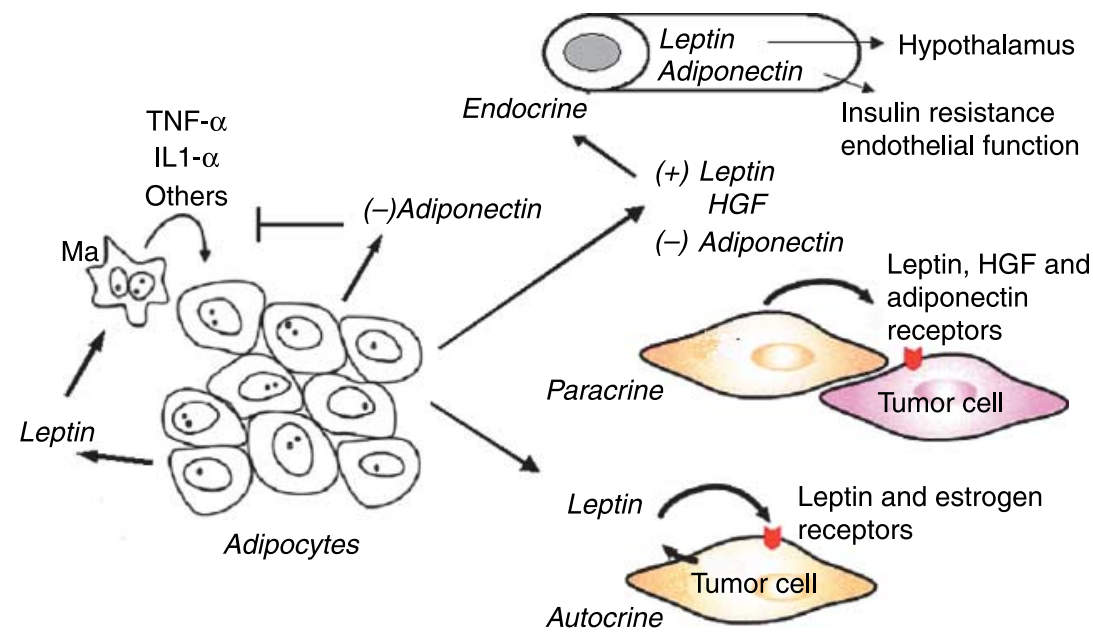

Figure 1 In obesity and breast cancer, adipokines (leptin, adiponectin, and HGF) circulate in the plasma to interact with preneoplastic or cancerous breast epithelium. Endocrine-, paracrine-, and autocrine-mediated relationships exist between leptin and the cellular microenvironment to support the growth of tumor cells via leptin and estrogen receptor activation. A paracrine relationship exists between HGF-synthesizing adipocytes and nearby mammary tumor cells to stimulate growth. Adiponectin exerts a direct growth-inhibitory effect on the tumor cells, blocks leptin secretion from surrounding breast adipose tissue, and prevents macrophages from producing inflammatory cytokines (TNF- $\alpha$ and IL-1 $\beta$ ). HGF, hepatocyte growth factor; TNF- $\alpha$, tumor necrosis factor- $\alpha$; IL-1 $\beta$, interleukin-1 $\beta$; Ma, macrophage. 
growth of ER-positive human breast cancer cell lines, as reflected in an enhanced uptake of bromodeoxyuridine: ER-negative cell lines were not included in this study. Iyengar et al. (2003) have taken a systemic approach using the powerful techniques of microarray analysis and luciferase reporter assays to study adipocyte-secreted factors which synergistically promote mammary tumorigenesis. They detected the presence of unidentified factors which induced NF- $\kappa \mathrm{B}$ and cyclin D1 production in MCF-7 cells, and promoted cell motility, migration, and angiogenesis.

Celis et al. (2005) performed a detailed proteomic analysis of breast adipose tissue collected from sites remote from ER-negative, high grade, tumors which were present in young premenopausal women, and who in consequence were at a high risk for recurrence. Histological examination of these cancers had shown how the tumor cells interdigitated with and spread through the adipose tissue providing the proximity necessary for maximally effective paracrine activity; samples for analysis were taken away from the tumor mass to avoid erroneous inclusion of autocrine factors secreted by the cancer cells. Among the 359 proteins that were identified were signaling molecules, hormones, cytokines and growth factors, including leptin, TNF- $\alpha$, IL-6, HGF, and vascular endothelial growth factor (VEGF). A similar analysis of the interstitial fluid that bathes the breast cancer cells and provides their immediate microenvironment revealed the presence of the same adipokines among over nearly 100 different cytokines and growth factors.

\section{Leptin}

Leptin is a mitogen for various cell types, including myelocytic and primitive hematopoietic progenitor cells (Bennett et al. 1996), normal and transformed breast epithelial cells (Hu et al. 2002, Somasundar et al. 2003), and vascular endothelial cells (Park et al. 2001, Artwohl et al. 2002). It can also exert antiapoptotic effects (Artwohl et al. 2002, RouetBenzineb et al. 2004), so further promoting cell proliferation. The critical role of angiogenesis in breast cancer and the angiogenic properties of leptin and VEGF were reviewed by Rose et al. (2002); the two angiogenic factors act synergistically, and so their co-production in adipose tissue has added significance both for wound healing and for breast cancer progression.

The completion of a paracrine loop requires the presence of a specific ligand-binding receptor on the target cell. The leptin receptor occurs in multiple forms, only one of which, the long form (LRb or
OBRI) has an intracellular domain of sufficient length to provide for full signal-transducing capabilities. Early on, it was considered that the short forms of the leptin receptor were devoid of signaling activity. However, by a series of transfection experiments, it is now known that the LRb can activate signal transducer and activator of transcription (STAT) factors 1, 3, and 6 , mitogen-activated protein kinase (MAPK) protein (Baumann et al. 1996, Yamashita et al. 1998), and c-fos gene transcription (Bjorbaek et al. 1997); whereas the short isoform mainly activates MAPK protein, and has little effect on STAT activation (Bjorbaek et al. 1997, Yamashita et al. 1998).

Both the long and short forms were shown to be present in a nonmalignant human breast epithelial cell line (Hu et al. 2002) and some human breast cancer cell lines (Dieudonne et al. 2002, Hu et al. 2002, Laud et al. 2002, Frankenberry et al. 2006), indicating the potential for a paracrine mitotic interaction between leptin synthesized by the surrounding adipocytes and the target mammary cells. Laud et al. (2002) reported that both forms occur in the ER-positive MCF-7 and T47D human breast cancer cell lines; they were also present in the epithelial cells of all of 20 primary breast cancers, only 5 of which were ER-positive. Later, Garofalo et al. (2004) examined the leptin receptor status of both ER-positive and ER-negative breast cancer cell lines and detected several isoforms by western blotting. Most significantly, only the ER-positive MCF-7 and T47D lines expressed substantial quantities of $\mathrm{LRb}$; the shorter forms were well represented in the highly invasive, metastatic, ER-negative breast cancer cell lines. Functionality of the breast epithelial cell leptin receptors was established by demonstrating that the proliferation of ER-positive cell lines in culture was stimulated in the presence of exogenous leptin (Dieudonne et al. 2002, Hu et al. 2002, Laud et al. 2002, Garofalo et al. 2004).

Unfortunately, Garofalo et al. (2004) did not report on the responsiveness of their two ER-negative cell lines to exogenous leptin. However, Vona-Davis and her colleagues showed that growth of the ER-negative HTB-26 cells derived from the highly metastatic MDA-MB-231 human breast cancer cell line by $M D R-1$ gene transfection, as well as the ER-positive MCF-7 and ZR-75-1 cell lines, were stimulated in experiments in vitro by leptin at a concentration of $40 \mathrm{ng} / \mathrm{ml}$ (Somasundar et al. 2003, Frankenberry et al. 2006). These mitogenic effects were not a consequence of altered leptin receptor expression in the ER-negative cell line, but directly related to the activation of extracellular signal-regulated kinase (ERK) and protein kinase B (Akt) signaling pathways, involved 
in breast cancer cell proliferation. To date, the prevailing hypothesis has been that leptin's effects were mediated primarily through ER action. However, this important finding suggests that leptin may stimulate ER-negative breast cancer cells by altering mitogenic signaling pathways to promote cancer pathogenesis.

Mammary epithelial cells display an absolute requirement for EGF and insulin-like growth factor (IGF) for cell proliferation and migration (Ram et al. 1995, Stull et al. 2002, Cui et al. 2006). In addition, (IGF-I) has been shown to cause activation of EGFR and consequently induction of the ERK pathways in breast cancer cells through a matrix metalloproteinasedependent mechanism (Gilmore et al. 2002). Leptin induced the phosphorylation of these receptors in gastric cancers suggesting that leptin is working in an autocrine or a paracrine manner (Shida et al. 2005). Further studies are needed to determine whether the leptin signal can interact with the EGF and IGF receptors in human breast cancer cells.

The reported mean values for serum or plasma leptin concentrations in breast cancer patients ranged from $13.57 \pm 0.66$ (Han et al. 2005) to $39.6 \pm 16.3 \mathrm{ng} / \mathrm{ml}$ (Coskun et al. 2003). The lowest concentrations that induced significant increases in human breast cancer cell proliferation in vitro were reported to be 25 (Hu et al. 2002) and $40 \mathrm{ng} / \mathrm{ml}$ (Frankenberry et al. 2006). While these data may suggest that cell culture experiments are biologically relevant to events occurring in the human, the situation is complicated. Circulating leptin, as assayed by an RIA or ELISA technique, includes a variable fraction of between 10 and $40 \%$ bound to a highaffinity, nonalbumin, high molecular weight protein (McConway et al. 2000) which has been identified as the soluble human leptin receptor (Lammert et al. 2001, Ogier et al. 2002), and may render the bound fraction biologically unavailable. Another point to consider is that concentrations of leptin found in serum may not reflect those secreted by adipocytes into the extracellular fluid surrounding the breast cancer cells and available for paracrine stimulation.

A number of animal studies have been initiated to understand the mechanisms that are associated with obesity, leptin, and mammary tumor development. It has been known for more than a decade that leptin levels are usually increased in obese animals (Frederich et al. 1995). Elegant studies by Cleary et al. $(2003,2004)$ have shown that genetically obese, leptin-deficient mice $\left(o b^{-} / o b^{-}\right)$or mice lacking a functional $O B-R\left(\mathrm{db}^{-} / \mathrm{d} b^{-}\right)$fail to develop oncogeneinduced mammary tumors. The data clearly suggest the relevance of leptin/OB-R signaling to mammary tumorigenesis. Hakkak et al. (2005) used a model of mammary carcinogenesis induced by the carcinogen 7,12-dimethylbenz(a)anthracene (DMBA), in obese Zucker rats $(f a l f a)$ against lean controls and showed that the presence of obesity increased susceptibility to the carcinogen. Obese Zucker rats develop hyperinsulinemia and insulin resistance and typically have threefold higher leptin levels than their lean counterparts. Further experimental studies are needed to distinguish between the effects of elevated insulin and leptin levels. Leptin signaling can increase other factors that contribute to cell proliferation and angiogenesis in mammary tumor growth. Gonzalez et al. (2006) reported that leptin signaling promotes growth and increases the expression of VEGF and VEGF-R2 in mammary tumors. Moreover, treatment of syngeneic mice with LPrA2, a small peptide leptin receptor antagonist, slowed tumor cell growth and reduced tumor burden. The inhibition of leptin signaling provides an attractive target for breast cancer therapy and may be clinically useful for prevention of disease in high-risk patients.

\section{Adiponectin}

As a result of the positive findings from epidemiological studies of adiponectin and cancer risk attention is turning to the effects of this adipokine on tumor cell biology. In experiments with human breast cancer cell lines, Kang et al. (2005) showed that adiponectin at a concentration of $30 \mu \mathrm{g} / \mathrm{ml}$ produced a $40 \%$ inhibition of growth, together with evidence of apoptotic activity, in the ER-negative MDA-MB-231 cell line, which is highly tumorigenic and metastatic in athymic nude mice (Rose et al. 1994). However, only minor effects were seen on two other ER-negative lines; the HS578T cell line which is representative of the rarely occurring breast carcinosarcomas and the SK-Br-3 line which was derived from an invasive ductal carcinoma. In addition, there was no inhibition of the ER-positive MCF-7 cell line in these experiments.

In contrast to these results, Dieudonne et al. (2006) performed a detailed study of the effects of adiponectin on MCF-7 cells and did find a reduction in cell number after incubation with the adipokine at the low concentration of $25 \mathrm{ng} / \mathrm{ml}$. Furthermore, stimulation of apoptosis occurred with induction of p53 and Bax expression and a decrease in Bcl-2 mRNA. Of particular interest, the growth stimulation of this particular MCF-7 cell line by estradiol was suppressed completely by the presence of adiponectin. While the cause of this discrepancy between the results reported by Kang et al. (2005) and Dieudonne et al. (2006) 
requires investigation, it may have arisen from the biological variations which have been recognized in the several lines of MCF-7 cells used by different laboratories (Osborne et al. 1987), or the composition of the culture media.

There are two molecular species of receptor for adiponectin. AdipoR1 is a receptor for globular adiponectin and is highly expressed in skeletal muscle. AdipoR2 is a receptor for the full-length $\mathrm{f}$-adiponectin and is mainly expressed in the liver (reviewed by Matsuzawa 2005). AdipoR1 is also highly expressed in human adipose tissue, suggesting that adiponectin can exert effects on adipocytes by a paracrine/autocrine mechanism (Rasmussen et al. 2006). Kang et al. (2005) did not attempt to demonstrate the presence of adiponectin receptors on MDA-MB-231 cells, but Dieudonne et al. (2006) showed that both their MCF7 cell line and MDA-MB-231 cells expressed AdipoR1 and AdipoR2 mRNA.

Reports of the suppressive effect of adiponectin on breast cancer cell growth in vitro, together with the presence of receptors for the ligand protein, are consistent with both endocrine and paracrine modes of action at the level of the tumor cell. Mantzoros and colleagues (Barb et al. 2006, Kelesidis et al. 2006) showed that adiponectin can act on T47D breast cancer cells directly and alter downstream signaling pathways. The effects of adiponectin on growth were mediated by the activation of ERK1/2 and not by adenosine monophosphate-activated protein kinase (AMPK). One could speculate that ERK1/2 activation may be acting as a negative regulator of the adiponectin receptor. More studies are needed to address the molecular mechanisms associated with adiponectin in breast malignancy.

Brakenhielm et al. (2004) found that adiponectin suppressed the growth of microvessel endothelial cells by the activation of the caspase cascade, which again contrasts with the Bcl-2-inducing, antiapoptotic, proangiogenic activity of leptin on these cells (Artwohl et al. 2002). In the same publication, these investigators also demonstrated that in an animal model, the infusion of adiponectin into highly vascularized mouse fibrosarcomas produced suppression of tumor growth which may have involved direct adiponectin-induced tumor cell death, but was certainly associated with loss of growth-supporting angiogenesis.

\section{Hepatocyte growth factor (HGF)}

HGF and its receptor Met, a tyrosine kinase product of the c-met protooncogene, have a role in both normal and neoplastic epithelial tissue development (Bellusci et al. 1994, Brinkmann et al. 1995, Niranjan et al. 1995). A paracrine relationship between HGF-synthesizing adipocytes and breast cancer cell proliferation was suggested experimentally by Rahimi et al. (1994). They showed that culture medium conditioned by 3T3L1 adipocytes stimulated growth of Met-expressing SP1 mouse mammary carcinoma cells in vitro, and that the mitogen produced by the fat cells was HGF. However, HGF has been found not to be directly stimulatory for the growth of human breast cancer cell lines.

Edakuni et al. (2001) studied the expression of Met and HGF in 81 human breast cancer tissues by a combination of immunohistochemistry and in situ hybridization. HGF and its receptor were expressed in both the cancer and stromal cells, so there was the potential for both paracrine and autocrine stimulation of tumor growth and invasion. The investigators designated a 'front acceleration pattern' as existing when the HGF and Met were most prominent at the growing tumor edge. The co-expression of the ligand and its receptor at the cancer front was found to correlate with histological grade and a high Ki-67 labeling index, and with reduced patient survival, results which suggest that the HGF-Met pathway acts in a paracrine/autocrine manner at the cancer front to promote tumor growth and sustained invasion.

Consistent with its association with an aggressive breast cancer phenotype and the observations reported by Edakuni et al. (2001), one of the biological properties of HGF is the ability to break down adherent junctions in epithelial cell colonies and promote cell dispersal: in tumor cells, this enhanced motility, together with an accompanying induction of proteolytic enzyme activity, stimulates invasive capacity (Bellusci et al. 1994, Kermorgant et al. 2001, Fujiuchi et al. 2003). Cancer cells were also found to secrete factors which can exert paracrine activity on fibroblasts to enhance their production of HGF; this fibroblastderived HGF can then itself behave in a paracrine manner to stimulate tumor cell invasion (Matsumoto \& Nakamura 2006).

In addition to its direct effects on breast cancer cell biological behavior, HGF has a stimulatory action on tumor-related angiogenesis. Vascular endothelial cells express Met, and HGF exerts potent angiogenic activity (Rosen et al. 1993) by a paracrine mechanism. Similar to leptin, it acts synergistically with VEGF (Van Belle et al. 1998). Finally, Martin et al. (2003) have shown that treatment with an HGF antagonist suppressed angiogenic activity and the growth of the ER-negative MDA-MB-231 human breast cancer cell line in a nude mouse model. 


\section{Breast cancer cell-produced estrogens and adipokines: autocrine factors}

\section{Estrogens}

Breast cancer autocrine activity which involves the estrogens requires that the tumor cell is ER-positive, and that it expresses both the aromatase system required for the synthesis of estrone from androstenedione, and the $17 \beta$-hydroxysteroid dehydrogenase necessary for the conversion of estrone to estradiol (Santen et al. 1998, de Jong et al. 2001, Suzuki et al. 2005, Purohit et al. 2006). Santen et al. (1998) examined aromatase levels in solid tumors by immunohistochemistry, and found that in $62 \%$ of 26 tumors, the enzyme was expressed in both the breast cancer epithelial cells and the stromal cells. However, it appeared that the most important source of aromatase activity was stromal cells, a conclusion also reached by Suzuki et al. (2005), with the implication that the paracrine mechanism of local estrogenic stimulation may dominate over autocrinemediated stimulation.

In addition to aromatase, $17 \beta$-hydroxysteroid dehydrogenase type 1 has a key role in the synthesis of estradiol by breast cancer tissues (Suzuki et al. 2005, Purohit et al. 2006, Sasano et al. 2006); the high concentrations of estradiol found in breast cancers is probably due to the high activity of the dehydrogenase which is induced by tumor-derived growth factors, and IL-6 and TNF- $\alpha$ derived from macrophages which infiltrate the tumor and the adjacent adipose tissue.

\section{Leptin}

O'Brien et al. (1999) appear to have been the first to describe the presence of leptin mRNA and the corresponding protein in both ER-positive and ER-negative human breast cancer cell lines and solid breast cancers. Later, Ishikawa et al. (2004) showed that immunohistochemically reactive leptin protein was expressed by both normal human breast epithelial cells and carcinoma cells; in $92 \%$ of 70 cancers, it was considered to be overexpressed as judged by the staining intensity. Leptin receptors were detected in the malignant epithelial cells of $83 \%$ of 76 invasive ductal breast carcinomas, but not in normal cells; moreover, the expression of the receptor protein and leptin overexpression were both associated with a high propensity for metastasis and a low survival rate. Ishikawa et al. (2004) concluded from their results that leptin exerts autocrine activity at the tumor site to enhance the metastatic capacity of breast cancer cells.
Similar results were obtained by Garofalo et al. (2006). They used immunohistochemistry to determine the expression of leptin and its receptor in 148 primary breast cancers, 66 lymph node metastases, and 99 cases of benign breast disease. Both the adipokine and its receptor were overexpressed in malignant breast epithelial cells when compared with noncancerous tissues. There was a variable degree of leptin expression between the individual cancers, which was similar in the primary and metastatic lesions. Leptin receptor expression was also increased in the cancer tissues. A high degree of leptin expression was associated particularly with poorly differentiated cancers, but did not correlate with primary tumor size, or the presence of lymph node metastases.

Miyoshi et al. (2006) determined the expression of mRNA for both the long and short forms of the leptin receptor in 91 breast cancer tissues and combined these results with the serum leptin concentrations and the intratumoral leptin mRNA expression in order to seek correlations with patients' prognosis. The receptor mRNA levels on their own did not correlate with any of the pathological predictors of prognosis which were examined, or with the eventual patient outcome. Further analysis showed that the relapse-free survival rates were lower in the subgroups of patients who had high receptor mRNA levels and also high intratumoral and/or serum leptin concentrations, relationships which again were compatible with an autocrine mechanism.

Chen et al. (2006b) reported that the autoregulation of leptin augments its signal by stimulating expressions of itself and its receptor, an observation that further supports an autocrine function. Using the ER-positive cell line, ZR-75-1, the authors showed that leptin signaling enhanced the expression of cell cycle regulators, c-Myc and cyclin D1. Leptin also repressed the expression of tumor suppressor p53. It is interesting to note that Chen et al. (2006b) found that leptin together with estrogen had significantly stronger stimulation on ZR-75-1 growth in comparison with either leptin or estrogen alone, suggesting that leptin and estrogen do not share the same intracellular pathways.

\section{Estrogen-adipokine interactions}

In spite of the involvement of estrogens in breast cancer etiology and progression, $\sim 30 \%$ of these tumors do not express the ER and so are inherently refractory to antiestrogen therapy; another $40 \%$ are of particular interest to us because they possess ER, but fail to respond to hormonal manipulation (McGuire \& Clark 1983). 
Catalano et al. (2004) took a major step forward by showing that leptin can transcriptionally activate the ER in MCF-7 breast cancer cells without the involvement of estradiol; the adipokine induced nuclear localization of the receptor, with upregulation of the synthesis of $\mathrm{pS} 2$, an estrogen-inducible protein which is expressed in estrogen-responsive breast cancer cells. These results suggest one mechanism by which leptin may have an adverse effect on the potential benefit of estrogen withdrawal achievable by treatment with an aromatase inhibitor such as anastrozole. The second mechanism was suggested by Garofalo et al. (2004) in experiments which showed directly that leptin can interfere with antiestrogenic activity and the suppression of tumor cell proliferation. The antiestrogen was fulvestrant (Faslodex; ICI 182780 ), which is one of the newer generations of antiestrogenic compounds and acts by inducing degradation of the ER. This effect, and the ability of fulvestrant to inhibit the growth of MCF-7 cells, was impaired by the presence of leptin.

Other investigators have also produced evidence that functional crosstalk can occur between leptin and the ER/ligand system. For example, Tanaka et al. (2001) showed that in female rats, the serum leptin levels are increased during the proestrus stage of the estrus cycle and that induction of leptin mRNA expression occurs in adipose tissue. In women, a similar observation was reported by Machinal-Quelin et al. (2002); the administration of estradiol caused an increase in leptin mRNA expression and secretion of the adipokine from adipose tissue, a response which was blocked by an antiestrogen. The study by Miyoshi et al. (2006) reporting serum leptin concentrations, and the levels of expression of intratumoral leptin and leptin receptor mRNA in breast cancer patients, which we referred to earlier in the review, showed that the intratumoral leptin mRNA levels were significantly higher in ER-positive when compared with ER-negative tumors. A reasonable explanation for this finding and proposed by the investigators is that leptin synthesized within the tumor tissue is specifically, or at least preferentially, involved in the growth stimulation of estrogendependent breast cancers by an autocrine mechanism.

The involvement of leptin in the paracrine stimulation of estrogen-responsive tissues is also supported by its capacity to induce aromatase synthesis in stromal cells isolated from s.c. and breast adipose tissues of premenopausal women; however, the significance of this observation needs further examination as an elevation in aromatase activity only occurred in samples from some of the donor women and at high leptin concentrations (Magoffin et al. 1999).
Catalano et al. (2003) reported that leptin can induce cytochrome $\mathrm{P} 450$ aromatase mRNA expression and the level and activity of the enzyme protein in MCF-7 breast cancer cells and that this involves MAPK and STAT signaling and an elevation in AP-1 DNA-binding activity. AP-1 complexes are activated by peptide growth factors and steroid hormones in both normal and transformed human breast epithelial cells, but the effect of inhibition of AP-1 activity on breast cancer cell lines is not consistent; in one study, the growth of MCF-7 cells was suppressed, but other lines, including the ER-positive T47D cell line, were unaffected (Ludes-Meyers et al. 2001). At present, the biological significance of breast cancer cell aromatase is uncertain. The activity level in MCF-7 cells is much lower than that in breast fibroblasts (Miller et al. 1997, Singh et al. 1997). Whether the aromatase present in breast cancer epithelial cells, even after stimulation by leptin, is sufficient to provide for estrogen biosynthesis at a level which can produce a significant degree of paracrine and autocrine growth stimulation, remains to be determined.

Among the other adiposity-associated cytokines/adipokines, TNF- $\alpha$ and IL-6 are also inducers of aromatase (Miller et al. 1997, Singh et al. 1997, Purohit et al. 2002) and 17ß-hydroxysteroid dehydrogenase (Purohit et al. 2002) activity, although Singh et al. (1997) found that while TNF- $\alpha$ stimulated the enzyme system in breast fibroblasts, it reduced further the already low activity in MCF-7 cells. Zhao et al. (1996) showed that the stimulation by TNF- $\alpha$, as in the case of leptin, involves increased AP-1-binding activity, c-fos and c-jun.

Miller et al. (1997) reported that both aromatase mRNA and STAT nuclear binding showed positive correlations with aromatase activity in vitro and that tumor extracts could induce aromatase in breast fibroblasts, perhaps due to the presence of IL-6. Purohit et al. (2003) showed that IL-6 together with its soluble receptor stimulated aromatase activity in fibroblasts isolated from normal breast tissue, and that this induction was blocked by a receptor-binding inactive mutated form of IL-6.

The increased infiltration of adipose tissue by TNF-secreting macrophages which occurs in obesity (Weisberg et al. 2003) provides a source of TNF- $\alpha$ which, by its involvement in the increased synthesis of estrogens from C19 steroid, may contribute to the increased breast cancer risk in obese postmenopausal women. 


\section{Commentary}

One issue which is confounding the results obtained from epidemiological studies of the potential roles of adipokines in breast cancer risk and subsequent tumor behavior may be the relative importance of their behavior as endocrine, paracrine, and autocrine factors. This raises the question of the extent to which assays performed on blood samples reflect the level of adipokine production by the breast adipose tissue and the potential for paracrine interaction with the preneoplastic or cancerous breast epithelium, and the similar local production by tumor cells and target interaction which is autocrine in nature. The problem is typified by leptin, where studies of serum concentrations and breast cancer risk have produced such a collection of inconsistent results (Table 3).

In this context, it is noteworthy that in the small study by Tessitore et al. (2000), which demonstrated a positive relationship between blood leptin levels and breast cancer risk, the degree of leptin mRNA expression in the peritumoral adipose tissue was also determined and was significantly higher in the breast cancer patients than the control women. Miyoshi et al. (2006), in their study of breast cancer prognosis and leptin and leptin receptor expression referred to earlier, determined the levels of leptin mRNA expression not only in the tumor epithelial cells, but also in the corresponding adipose tissues where they found them to be much higher. These results suggest that the paracrine relationship between breast cancer cells and the surrounding breast adipose tissue is more important in terms of its bioregulatory effects than is a potential leptin-mediated autocrine loop. In support of this interpretation is the observation by Chen et al. (2006a) who found no significant effect of the surgical removal of tumors on the high serum leptin concentrations in their breast cancer patients. This finding is consistent with the idea that tumor leptin production is a minor source of the adipokine, while the unexcised adipose tissue remains a major contributor to the circulating levels.

In contrast to leptin, a significant role for adiponectin, specifically a protective one against the risk of developing breast cancer, is supported by the epidemiological evidence: in three reported studies, reduced circulating adiponectin concentrations were associated with a significant increase in breast cancer risk. Further work is needed to dissect out the implied causal relationship between low adiponectin production by the adipocytes and low blood levels on tumor cellrelated angiogenesis (Rose et al. 2004), and to build on the recent results of culture experiments in vitro which showed that adiponectin can suppress directly breast cancer cell proliferation (Kang et al. 2005, Barb et al. 2006, Dieudonne et al. 2006, Kelesidis et al. 2006).

Angiogenesis, the process by which new blood vessels are formed from preexisting vasculature, is essential for cancer growth, invasion, and metastasis, and the density of the microvessels within the tumor mass is a prognostic indicator in breast cancer patients (Engels et al. 1997). VEGF, which is critical for tumorrelated angiogenesis, is overexpressed by breast cancer stromal cells which provides for paracrine stimulation of endothelial cells. In addition to stromal cells, VEGF is produced by neoplastic epithelial cells (Boudreau \& Myers 2003 and the references therein).

Adipose tissue possesses a complex network of capillaries that can undergo expansion and regression. The processes of angiogenesis and adipogenesis are coordinated with a paracrine interaction between neovascularization in adipose tissue and adipocyte differentiation which allows for control of adipogenesis by vascular endothelial cells (Fukumura et al. 2003, Neels et al. 2004). This is mediated largely by VEGF (Hausman \& Richardson 2004), but most likely also involves leptin, given its demonstrated angiogenic properties and its role in the neovascularization of wound healing (Murad et al. 2003), and, perhaps, other angiogenic adipokines, such as HGF (Rosen et al. 1993), HB-EGF (Abramovitch et al. 1998), and TNF- $\alpha$ (Frater-Schroder et al. 1987).

The angiogenesis which takes place in adipose tissue offers an ideal environment for tumor development, and particularly so in the case of emerging invasive breast cancer cells which are growing in the mammary adipose tissue mass. This concept, and its relation to obesity-associated adipokine production, deserves clinical and experimental investigation.

\section{Acknowledgement}

The authors declare that there is no conflict of interest that would prejudice the impartiality of this scientific work.

\section{References}

Abramovitch R, Neeman M, Reich R, Stein I, Keshet E, Abraham J, Solomon A \& Marikovsky M 1998

Intercellular communication between vascular smooth muscle and endothelial cells mediated by heparin-binding epidermal growth factor-like growth factor and vascular endothelial growth factor. FEBS Letters 425 441-447.

Artwohl M, Roden M, Holsenbein T, Freudenthaler A, Waldhausl W \& Baumgartner-Parzer SM 2002 
Modulation by leptin of proliferation and apoptosis in vascular endothelial cells. International Journal of Obesity and Related Metabolic Disorders 26 577-580.

Bajoria R, Sooranna SR, Ward BS \& Chatterjee R 2002 Prospective function of placental leptin at maternal-fetal interface. Placenta 23 103-115.

Barb D, Pazaitou-Panayiotou K \& Mantzoros CS 2006 Adiponectin: a link between obesity and cancer. Expert Opinions in Investigative Drugs 15 917-931.

Baumann H, Morella KK, White DW, Dembski M, Bailon PS, Kim H, Lai CF \& Tartaglia LA 1996 The full-length receptor has signaling capabilities of interleukin 6-type cytokine receptors. PNAS 93 8374-8378.

Bell LN, Ward JL, Degawa-Yamauchi M, Bovenkerk JE, Jones R, Cacucci BM, Gupta CE, Sheridan C, Sheridan K, Shankar SS et al. 2006 Adipose tissue production of hepatocyte growth factor contributes to elevated serum HGF in obesity. American Journal of Physiology, Endocrinology and Metabolism 291 E843-E848.

Bellusci S, Moens G, Guadino G, Comoglio P, Nakamura T, Thiery JP \& Jouanneau J 1994 Creation of an hepatocyte growth factor/scatter factor autocrine loop in carcinoma cells induces invasive properties associated with increased tumorigenicity. Oncogene 9 1091-1099.

Bennett BD, Solar GP, Yuan JQ, Mathias J, Thomas GR \& Matthews W 1996 A role for leptin and its cognate receptor in hematopoiesis. Current Biology 6 1170-1180.

Bjorbaek C, Uotani S, da Silva B \& Flier JS 1997 Divergent signaling capacities of the long and short isoforms of the leptin receptor. Journal of Biological Chemistry 272 32686-32695.

Blundell JE, Goodson S \& Halford JC 2001 Regulation of appetite: role of leptin in signaling systems for drive and satiety. International Journal of Obesity and Related Metabolic Disorders 25 S29-S34.

Boudreau N \& Myers C 2003 Breast cancer-induced angiogenesis: multiple mechanisms and the role of the microenvironment. Breast Cancer Research 5 140-146.

Brakenhielm E, Veitonmaki N, Cao R, Kihara S, Matsuzawa Y, Zhivotovsky B, Funahashi T \& Cao Y 2004 Adiponectininduced antiangiogenesis and antitumor activity involve caspase-mediated endothelial cell apoptosis. PNAS 101 2476-2481.

Brinkmann V, Foroutan H, Sachs M, Weidner KM \& Birchmeier W 1995 Hepatocyte growth factor/scatter factor induces a variety of tissue-specific morphogenic programs in epithelial cells. Journal of Cell Biology 131 1573-1586.

Bulun SE, Mahendroo MS \& Simpson ER 1994 Aromatase gene expression in adipose tissue: relationship to breast cancer. Journal of Steroid Biochemistry and Molecular Biology 49 319-326.

Catalano S, Marsico S, Giordano C, Mauro L, Rizza P, Panno ML \& Ando S 2003 Leptin enhances, via AP-1, expression of aromatase in the MCF-7 cell line. Journal of Biological Chemistry 278 28668-28676.
Catalano S, Mauro L, Marsico S, Giordano C, Rizza P, Rago V, Montanora D, Maggiolini M, Panno ML \& Ando S 2004 Leptin induces, via ERK1/ERK2 signal, functional activation of estrogen receptor alpha in MCF-7 cells. Journal of Biological Chemistry 279 19908-19915.

Celis JE, Moreira JM, Cabezon T, Gromov P, Friis E, Rank F \& Gromova I 2005 Indentification of extracellular and intracellular signaling components of the mammary adipose tissue and its interstitial fluid in high risk breast cancer patients: toward dissecting the molecular circuitry of epithelial-adipocyte stromal cell interactions. Molecular and Cellular Proteomics 4 492-522.

Cella F, Giordano G \& Cordera R 2000 Serum leptin concentrations during the menstrual cycle in normalweight women: effects of an oral triphasic estrogenprogestin medication. European Journal of Endocrinology 142 174-178.

Cento RM, Proto C, Spada RS, Napolitano V, Ciampelli M, Cucinelli F \& Lanzone A 1999 Leptin levels in menopause: effect of estrogen replacement therapy. Hormone Research 52 269-273.

Chen DC, Chung YF, Yeh YT, Chaung HC, Kuo FC, Fu OY, Chen HY, Hou MF \& Yuan SS 2006a Serum adiponectin and leptin levels in Taiwanese breast cancer patients. Cancer Letters 237 109-114.

Chen C, Chang YC, Liu CL, Chang KJ \& Guo IC $2006 b$ Leptin-induced growth of human ZR-75-1 breast cancer cells is associated with up-regulation of cyclin D1 and c-Myc and down-regulation of tumor suppressor p53 and p21WAF1/CIP1. Breast Cancer Research and Treatment 98 121-132.

Cleary MP, Phillips FC, Getzin SC, Jacobson TL, Jacobson MK, Christensen TA, Juneja SC, Grande JP \& Maihle NJ 2003 Genetically obese MMTV-TGF- $\alpha /$ Lepob Lepob female mice do not develop mammary tumors. Breast Cancer Research and Treatment 77 205-215.

Cleary MP, Juneja SC, Phillips FC, Hu X, Grande JP \& Maihle NJ 2004 Leptin receptor-deficient MMTVTGF- $\alpha /$ Lepdb Lepdb female mice do not develop mammary tumors. Experimental Biology and Medicine 229 182-193.

Coskun U, Gunel N, Toruner FB, Sancak B, Onuk E, Bayram O, Cengiz O, Yilmaz E, Elbeg S \& Ozkan S 2003 Serum leptin, prolactin and vascular endothelial growth factor (VEGF) levels in patients with breast cancer. Neoplasma 50 41-46.

Crichton MB, Nichols JE, Zhao Y, Bulun SE \& Simpson ER 1996 Expression of transcripts of interleukin- 6 and related cytokines by human breast tumors, breast cancer cells and adipose stromal cells. Molecular and Cellular Endocrinology 118 215-220.

Cui X, Kim HJ, Kuiatse I, Kim H, Brown PH \& Lee AV 2006 Epidermal growth factor induces insulin receptor substrate-2 in breast cancer cells via c-Jun $\mathrm{NH}(2)$-terminal kinase/activator protein-1 signaling to regulate cell migration. Cancer Research 66 5304-5313. 
Cymbaluk A, Chudecka-Glaz A, Rzepka-Gorska I 2007 Leptin levels in serum depending on body mass index in patients with endometrial hyperplasia and cancer. European Journal of Obstetrics, Gynaecology and Reproductive Biology [in press].

Del Giudice ME, Fantus IG, Ezzat S, McKeown-Eyssen G, Page D \& Goodwin PJ 1998 Insulin and related factors in premenopausal breast cancer risk. Breast Cancer Research and Treatment 47 111-120.

Dieudonne M-N, Machinal-Quelin F, Serazin-Leroy V, Leneveu MC, Pecquery R \& Giudicelli Y 2002 Leptin mediates a proliferative response in human MCF7 breast cancer cells. Biochemical and Biophysical Research Communications 293 622-628.

Dieudonne M-N, Bussiere M, Dos Santos E, Leneveu MC, Giudicelli Y \& Pecquery R 2006 Adiponectin mediates antiproliferative and apoptotic responses in human MCF7 breast cancer cells. Biochemical and Biophysical Research Communications 345 271-279.

Edakuni G, Sasatomi E, Satoh T, Tokunaga O \& Miyazaki K 2001 Expression of the hepatocyte growth factor/c-Met pathway is increased at the cancer front in breast carcinoma. Pathology International 51 172-178.

Engels K, Fox SB \& Harris AL 1997 Angiogenesis as a biologic and prongnostic indicator in human breast carcinoma. EXS 79 113-156.

Fain JN, Madan AK, Hiler ML, Cheema P \& Bahouth SW 2004 Comparison of the release of adipokines by adipose tissue, adipose tissue matrix, and adipocytes from visceral and subcutaneous abdominal adipose tissue of obese humans. Endocrinology 145 2273-2282.

Fischer S, Hanefeld M, Haffner SM, Fusch C, Schwanebeck U, Kohler C, Fucker K \& Julius U 2002 Insulin-resistant patients with type 2 diabetes mellitus have higher serum leptin levels independently of body fat mass. Acta Diabetologia 39 105-110.

Frankenberry KA, Skinner H, Somasundar P, McFadden DW \& Vona-Davis LC 2006 Leptin receptor expression and cell signaling in breast cancer. International Journal of Oncology 28 985-993.

Franks PW, Brage S, Luan J, Ekelund U, Rahman M, Farooqi IS, Halsall I, O'Rahilly S \& Wareham NJ 2005 Leptin predicts a worsening of the features of the metabolic syndrome independently of obesity. Obesity Research 13 1476-1484.

Frater-Schroder M, Risau W, Hallmann R, Gautschi P \& Bohlen P 1987 Tumor necrosis factor type alpha, a potent inhibitor of endothelial cell growth in vitro, is angiogenic in vivo. PNAS 84 5277-5281.

Frederich RC, Hamann A, Anderson S, Lollmann B, Lowell BB \& Flier JS 1995 Leptin levels reflect body lipid content in mice: evidence for diet-induced resistance to leptin action. Nature Medicine 1 1311-1314.

Fujiuchi Y, Nagakawa O, Murakami K, Fuse H \& Saiki I 2003 Effect of hepatocyte growth factor on invasion of prostate cancer cell lines. Oncology Reports 10 1001-1006.
Fukumura D, Ushiyama A, Duda DG, Xu L, Tam J, Krishna V, Chatterjee K, Garkavtsev I \& Jain RK 2003 Paracrine regulation of angiogenesis and adipocyte differentiation during in vivo adipogenesis. Circulation Research 93 e88-e97.

Funahashi T, Nakamura T, Shimomura I, Maeda K, Kuriyama H, Takahashi M, Arita Y, Kihara S \& Matsuzawa Y 1999 Role of adipocytokines on the pathogenesis of atherosclerosis in visceral obesity. Internal Medicine 38 202-206.

Garofalo C, Sisci D \& Surmacz E 2004 Leptin interferes with the effects of the antiestrogen ICI 182, 780 in MCF-7 breast cancer cells. Clinical Cancer Research $\mathbf{1 0}$ 6466-6475.

Garofalo C, Koda M, Cascio S, Sulkowska M, KanczugaKoda L, Golaszewska J, Russo A, Sulkowski \& Surmacz E 2006 Increased expression of leptin and the leptin receptor as a marker of breast cancer progression: possible role of obesity-related stimuli. Clinical Cancer Research 12 1447-1453.

Geisthovel F, Jochmann N, Widjaja A, Horn R \& Brabant G 2004 Serum pattern of circulating free leptin, bound leptin, and soluble leptin receptor in the physiological menstrual cycle. Fertility and Sterility 81 398-402.

Gilmore AP, Valentin AJ, Wang P, Rangaer AM, Bundred N, O'Hare MJ, Wakeling A, Korsmeyer SJ \& Streuli CH 2002 Activation of BAD by therapeutic inhibition of epidermal growth factor receptor and transactivation by insulin-like growth factor receptor. Journal of Biological Chemistry 277 27643-27650.

Gonzalez RR, Cherfils S, Escobar M, Yoo JH, Carino C, Styer AK, Sullivan BT, Sakamoto H, Olawaiye A, Serikawa T et al. 2006 Leptin signaling promotes the growth of mammary tumors and increases the expression of vascular endothelial growth factor (VEGF) and its receptor tye two (VEGF-R2). Journal of Biological Chemistry 281 26320-26328.

Goodwin PJ, Ennis M, Pritchard KI, Trudeau ME, Koo J, Madarnas Y, Hartwick W, Hoffman B \& Hood N 2002 Fasting insulin and outcome in early-stage breast cancer: results of a prospective cohort study. Journal of Clinical Oncology 20 42-51.

Goodwin PJ, Ennis M, Fantus IG, Pritchard KI, Trudeau ME, Koo J \& Hood N 2005 Is leptin a mediator of adverse prognostic effects of obesity in breast cancer? Journal of Clinical Oncology 23 6037-6042.

Groschl M, Wagner R, Dorr HG, Blum W, Rascher W \& Dotsch J 2000 Variability of leptin values measured from different sample matrices. Hormone Research 54 26-31.

Hakkak R, Holley AW, MacLeod SL, Simpson PM, Fuchs GJ, Jo CH, Kieber-Emmons T \& Korourian S 2005 Obesity promotes 7,12-dimethylbenz(a)anthracene-induced mammary tumor development in female zucker rats. Breast Cancer Research 7 R627-R633.

Han C, Zhang HT, Du L, Liu X, Jing J, Zhao X, Yang X \& Tian B 2005 Serum levels of leptin, insulin, and lipids in relation to breast cancer in China. Endocrine 26 19-24. 
Harvie M, Hooper L \& Howell AH 2003 Central obesity and breast cancer risk: a systemic review. Obesity Reviews 4 157-173.

Hausman GJ \& Richardson RL 2004 Adipose tissue angiogenesis. Journal of Animal Science 82 925-934.

Hayase H, Nomura S, Abe T \& Izawa T 2002 Relation between fat distributions and several plasma adipocytokines after exercise training in premenopausal and postmenopausal women. Journal of Physiological Anthropology and Applied Human Science 21 105-113.

Hirose K, Toyama T, Iwata H, Takezaki T, Hamajima N \& Tajima K 2003 Insulin, insulin-like growth factor-I and breast cancer risk in Japanese women. Asian Pacific Journal of Cancer Prevention 4 239-246.

Hu X, Juneja SC, Maihle NJ \& Cleary MP 2002 Leptin-a growth factor in normal and malignant breast cells and for normal mammary gland development. Journal of National Cancer Institute 94 1704-1711.

Ishikawa M, Kitayama J \& Nagawa H 2004 Enhanced expression of leptin and leptin receptor (OB-R) in human breast cancer. Clinical Cancer Research 10 4325-4331.

Iyengar P, Combs TP, Shah SJ, Gouon-Evans V, Pollard JW, Albanese C, Flanagan L, Tenniswood MP, Guha C \& Lisanti MP 2003 Adipocyte-secreted factors synergistically promote mammary tumorigenesis through induction of anti-apoptotic transcriptional programs and protooncogene stabilization. Oncogene 22 6408-6423.

Jensen EV \& Jordan VC 2003 The estrogen receptor: a model for molecular medicine. Clinical Cancer Research 9 1980-1989.

Jin L, Zhang S, Burguera BG, Couce ME, Osamura RY, Kulig E \& Lloyd RV 2000 Leptin and leptin receptor expression in rat and mouse pituitary cells. Endocrinology 141 333-339.

de Jong PC, Blankenstein MA, van de Ven J, Nortier JW, Blijham GH \& Thijssen JH 2001 Importance of local aromatase activity in hormone-dependent breast cancer: a review. Breast 10 91-99.

Kang JH, Lee YY, Yu BY, Yang BS, Cho KH, Yoon do K \& Roh YK 2005 Adiponectin induces growth arrest and apoptosis of MDA-MB-231 breast cancer cell. Archives of Pharmacological Research 28 1263-1269.

Kelesidis I, Kelesidis T \& Mantzoros CS 2006 Adiponectin and cancer: a systematic review. British Journal of Cancer 94 1221-1225.

Kermorgant S, Aparicio T, Dessirier V, Lewin MJ \& Lehy T 2001 Hepatocyte growth factor induces colonic cancer cell invasiveness via enhanced motility and protease overproduction. Evidence for PI3 kinase and PKC involvement. Carcinogenesis 22 1037-1042.

Kern PA, Di Gregorio GB, Lu T, Rassouli N \& Ranganathan G 2003 Adiponectin ezpression from human adipose tissue: relation to obesity, insulin resistance, and tumor necrosis factor-alpha expression. Diabetes 52 1779-1785.

Key TJ, Appleby PN, Reeves GK, Roddam A, Dorgan JF, Longcope C, Stanczyk FZ, Stephenson HE Jr, Falk RT, Miller R et al. 2003 Body mass index, serum sex hormones, and breast cancer risk in postmenopausal women. Journal of the National Cancer Institute 95 1218-1226.

Kobayashi H, Ouchi N, Kihara S, Walsh K, Kumada M, Abe Y, Funahashi T \& Matsuzawa Y 2004 Selective suppression of endothelial cell apoptosis by the high molecular weight form of adiponectin. Circulation Research 94 e27-e31.

Korner A, Wabitsch M, Seidel B, Fischer-Posovszky P, Berthold A, Stumvoll M, Bluher M, Kratzsch J \& Kiess W 2005 Adiponectin expession in humans is dependent on differentiation of adipocytes and down-regulated by humoral serum components of high molecular weight. Biochemical and Biophysical Research Communications 337 540-550.

Lammert A, Kiess W, Bottner A, Glasow A \& Kratzsch J 2001 Soluble leptin receptor represents the main leptin binding activity in human blood. Biochemistry and Biophysics Research Communications 283 982-988.

Laud K, Gourdon I, Pessemesse L, Peyrat JP \& Djiane J 2002 Identification of leptin receptors in human breast cancer: functional activity in the T47-D breast cancer cell line. Molecular and Cellular Endocrinology 188 219-226.

Lawlor DA, Smith GD \& Ebrahim S 2004 Hyperinsulinaemia and increased risk of breast cancer: findings from the British Women's Heart and Health Study. Cancer Causes and Control 15 267-275.

Ludes-Meyers JH, Liu Y, Munoz-Medellin D, Hilsenbeck SG \& Brown PH 2001 AP-1 blockade inhibits the growth of normal and malignant breast cells. Oncogene 20 2771-2780.

MacDougald OA, Hwang CS, Fan H \& Lane MD 1995 Regulated expression of the obese gene product (leptin) in white adipose tissue and 3T3-L1 adipocytes. PNAS 92 9034-9037.

Machinal-Quelin F, Dieudonne M-N, Pecquery R, Leneveu MC \& Giudicelli Y 2002 Direct in vitro effects of androgens and estrogens on ob gene expression and leptin secretion in human adipose tissue. Endocrine 18 179-184.

Magoffin DA, Weitsman SR, Aagarwal SK \& Jakimiuk AJ 1999 Leptin regulation of aromatase activity in adipose stromal cells from regularly cycling women. Ginekologia Polska 70 1-7.

Manabe Y, Toda S, Miyazaki K \& Sugihara H 2003 Mature adipocytes, but not preadipocytes, promote the growth of breast carcinoma cells in collagen gel matrix culture through cancer-stromal cell interactions. Journal of Pathology 201 221-228.

Mantzoros C, Petridou E, Dessypris N, Chavelas C, Dalamaga M, Alexe DM, Papadiamantis Y, Markopoulos C, Spanos E, Chrousos G et al. 2004 Adiponectin and breast cancer risk. Journal of Clinical Endocrinology and Metabolism 89 1102-1107.

Martin TA, Parr C, Davies G, Watkins G, Lane J, Matsumoto K, Nakamura T, Mansel RE \& Jiang WG 2003 Growth and 
angiogenesis of human breast cancer in a nude mouse tumour model is reduced by NK4, a HGF/SF antagonist. Carcinogenesis 24 1317-1323.

Marttunen MB, Andersson S, Hietanen P, Karonen SL, Koistinen HA, Koivisto VA, Tiitinen A \& Ylikorkala O 2000 Antiestrogenic tamoxifen and toremifene increase serum leptin levels in postmenopausal breast cancer patients. Maturitas 35 175-179.

Matsumoto K \& Nakamura T 2006 Hepatocyte growth factor and the Met system as a mediator of tumor-stromal interactions. International Journal of Cancer 119 477-483.

Matsumoto S, Kishida K, Shimomura I, Maeda N, Nagaretani H, Matsuda M, Nishizawa H, Kihara S, Funahashi T, Matsuzawa Y et al. 2002 Increased plasma HB-EGF associated with obesity and coronary artery disease. Biochemical and Biophysical Research Communications 292 781-786.

Matsuzawa Y 2005 Adiponectin: Identification, physiology and clinical relevance in metabolic and vascular disease. Atherosclerosis 6 7-14.

McConway MG, Johnson D, Kelly A, Griffin D, Smith J \& Wallace AM 2000 Differences in circulating concentrations of total, free and bound leptin relate to gender and body composition in adult humans. Annals of Clinical Biochemistry 37 717-723.

McGuire WL \& Clark GM 1983 Progesterone receptors and human breast cancer. Breast Cancer Research and Treatment 3 157-163.

Meng L, Zhou J, Sasano H, Suzuki T, Zeitoun KM \& Bulun SE 2001 Tumor necrosis factor alpha and interleukin 11 secreted by malignant breast epithelial cells inhibit adipocyte differentiation by selectively down-regulating CCAAT/enhancer binding protein alpha and peroxisome proliferator-activated receptor gamma: mechanism of desmoplastic reaction. Cancer Research 61 2250-2255.

Mick GJ, Wany X \& McCormick K 2002 White adipocyte vascular endothelial growth factor: regulation by insulin. Endocrinology 143 948-953.

Miller WR, Mullen P, Sourdaine P, Watson C, Dixon JM \& Telford J 1997 Regulation of aromatase activity within the breast. Journal of Steroid Biochemistry and Molecular Biology 61 193-202.

Miyoshi Y, Funahashi T, Kihara S, Taguchi T, Tamaki Y, Matsuzawa Y \& Noguchi S 2003 Association of serum adiponectin levels with breast cancer risk. Clinical Cancer Research 9 5699-5704.

Miyoshi Y, Funahashi T, Tanaka S, Taguchi T, Tamaki Y, Shimomura I \& Noguchi S 2006 High expression of leptin receptor mRNA in breast cancer tissue predicts poor prognosis for patients with high, but not low, serum leptin levels. International Journal of Cancer 118 1414-1419.

Murad A, Nath AK, Cha ST, Demir E, Flores-Riveros J \& Sierra-Honigmann MR 2003 Leptin is an autocrine/paracrine regulator of wound healing. FASEB Journal 17 1895-1897.
Neels JG, Thinnes T \& Loskutoff DJ 2004 Angiogenesis in an in vivo model of adipose tissue development. FASEB Journal 18 983-985.

Niranjan B, Buluwela L, Yant J, Perusinghe N, Atherton A, Phippard D, Dale T, Gusterson B \& Kamalati T 1995 HGF/SF: a potent cytokine for mammary growth, morphogenesis and development. Development 121 2897-2908.

O’Brien SN, Welter BH \& Price TM 1999 Presence of leptin in breast cell lines and breast tumors. Biochemical and Biophysical Research Communications 259 695-698.

Ogier V, Ziegler O, Mejean L, Nicolas JP \& StrickerKrongrad A 2002 Obesity is associated with decreasing levels of the circulating soluble leptin receptor in humans. International Journal of Obesity Research and Metabolic Disorders 26 496-503.

Osborne CK, Hobbs K \& Trent JM 1987 Biological differences among MCF-7 human breast cancer cell lines from different laboratories. Breast Cancer Research and Treatment 9 111-121.

Ozet A, Arpaci F, Yilmaz MI, Ayta H, Ozturk B, Komurcu S, Yavuz AA, Tezcan Y \& Acikel C 2001 Effects of tamoxifen on the serum leptin level in patients with breast cancer. Japanese Journal of Clinical Oncology 31 424-427.

Park HY, Kwon HM, Lim HJ, Hong BK, Kee JY, Park BE, Jang Y, Cho SY \& Kim HS 2001 Potential role of leptin in angiogenesis: leptin induces endothelial cell proliferation and expression of matrix metalloproteinases in vivo and in vitro. Experimental and Molecular Medicine $\mathbf{3 3}$ 95-102.

Petridou E, Papadiamantis Y, Markopoulos C, Spanos E, Dessypris N \& Trichopoulos D 2000 Leptin and insulin growth factor I in relation to breast cancer (Greece). Cancer Causes and Control 11 383-388.

Petridou E, Belechri M, Dessypris N, Koukoulomatis P, Diakomanolis E, Spanos E \& Trichopoulos D 2002 Leptin and body mass index in relation to endometrial cancer risk. Annals of Nutrition and Metabolism 46 147-151.

Petridou E, Mantzoros C, Dessypris N, Koukoulomatis P, Addy C, Voulgaris Z, Chrousos G \& Trichopoulos D 2003 Plasma adiponectin concentrations in relation to endometrial cancer: a case-control study in Greece. Journal of Clinical Endocrinology and Metabolism $\mathbf{8 8}$ 993-997.

Purohit A, Newman SP \& Reed MJ 2002 The role of cytokines in regulating estrogen synthesis: implications for the etiology of breast cancer. Breast Cancer Research 4 65-69.

Purohit A, Singh A, Ghilchik MW, Serlupi-Crescenzi O \& Reed MJ 2003 Inhibition of IL-6+ IL-6 soluble receptorstimulated aromatase activity by the IL- 6 antagonist, Sant 7 , in breast tissue-derived fibroblasts. British Journal of Cancer 88 630-635.

Purohit A, Tutill HJ, Day JM, Chander SK, Lawrence HR, Allan GM, Fischer DS, Vicker N, Newman SP, Potter BV 
et al. 2006 The regulation and inhibition of 17betahydroxysteroid dehydrogenase in breast cancer. Molecular and Cellular Endocrinology 248 199-203.

Rahimi N, Saulnier R, Nakamura T, Park M \& Elliott B 1994 Role of hepatocyte growth factor in breast cancer: a novel mitogenic factor secreted by adipocytes. DNA and Cell Biology 13 1189-1197.

Ram TG, Kokeny KE, Dilts CA \& Ethier SP 1995 Mitogenic activity of neu differentiation factor/heregulin mimics that of epidermal growth factor and insulin-like growth factorI in human mammary epithelial cells. Journal of Cell Physiology 163 589-596.

Rasmussen MS, Lihn AS, Pedersen SB, Bruun JM, Rasmussen M \& Richelsen B 2006 Adiponectin receptors in human adipose tissue: effects of obesity, weight loss, and fat depots. Obesity Research 14 28-35.

Rehman J, Considine RV, Bovenkerk JE, Li J, Slavens CA, Jones RM \& March KL 2003 Obesity is associated with increased levels of circulating hepatocyte growth factor. Journal of the American College of Cardiology 41 1408-1413.

Rehman J, Traktuev D, Li J, Merfeld-Clauss S, Temm-Grove CJ, Bovenkerk JE, Pell CL, Johnstone BH, Considine RV \& March KL 2004 Secretion of angiogenic and antiapoptotic factors by human adipose stromal cells. Circulation 109 1292-1298.

Riad-Gabriel MG, Jinagouda SD, Sharma A, Boyadjian R \& Saad MF 1998 Changes in plasma leptin during the menstrual cycle. European Journal of Endocrinology 139 528-531.

Rose DP, Connolly JM \& Liu XH 1994 Effects of linoleic acid on the growth and metastasis of two human breast cancer cell lines in nude mice and the invasive capacity of these cell lines in vitro. Cancer Research $\mathbf{5 4}$ 6557-6562.

Rose DP, Gilhooly EM \& Nixon DW 2002 Adverse effects of obesity on breast cancer prognosis, and the biological actions of leptin (review). International Journal of Oncology 21 1285-1292.

Rose DP, Komninou D \& Stephenson GD 2004 Obesity, adipocytokines, and insulin resistance in breast cancer. Obesity Reviews 5 153-165.

Rosen EM, Grant DS, Kleinman HK, Goldberg ID, Bhargava MM, Nickoloff BJ, Kinsella JL \& Polverini P 1993 Scatter factor (hepatocyte growth factor) is a potent angiogenesis factor in vivo. Symposium of the Society of Experimental Biology 47 227-234.

Rouet-Benzineb P, Aparicio T, Guilmeau S, Pouzet C, Descatoire V, Buyse M \& Bado A 2004 Leptin counteracts sodium butyrate-induced apoptosis in human colon cancer HT-29 cells via NF-kappaB signaling. Journal of Biological Chemistry 279 16495-16502.

Santen RJ, Martel J, Hoagland M, Naftolin F, Roa L, Harada N, Hafer L, Zaino R, Pauley R \& Santner S 1998 Demonstration of aromatase activity and its regulation in breast tumor and benign breast fibroblasts. Breast Cancer Research and Treatment 49 s93-s99.
Sasano H, Suzuki T, Nakata T \& Moriya T 2006 New development in intracrinology of breast carcinoma. Breast Cancer 13 129-136.

Sauter ER, Garofalo C, Hewett J, Hewett JE, Morelli C \& Surmacz E 2004 Leptin expression in breast nipple aspirate fluid (NAF) and serum is influenced by body mass index (BMI) but not by the presence of breast cancer. Hormone and Metabolic Research 36 336-340.

Sheen-Chen SM, Liu YW, Eng HL \& Chou FF 2005 Serum levels of hepatocyte growth factor in patients with breast cancer. Cancer Epidemiology, Biomarkers and Prevention 14 715-717.

Shida D, Kitayama J, Mori K, Watanabe T \& Nagawa H 2005 Transactivation of epidermal growth factor receptor is involved in leptin-induced activation of janus-activated kinase 2 and extracellular signal-regulated kinase $1 / 2$ in human gastric cancer cells. Cancer Research 65 9159-9163.

Simons PJ, van den Pangaart PS, van Roomen CP, Aerts JM \& Boon L 2005 Cytokine-mediated modulation of leptin and adiponectin secretion during in vitro adipogenesis: evidence that tumor necrosis factor-alpha and interleukin1beta-treated human predipocytes are potent leptin producers. Cytokine 32 94-103.

Singh A, Purohit A, Duncan LJ, Mokbel K, Ghilchik MW \& Reed MJ 1997 Control of aromatase activity in breast tumours: the role of the immune system. Journal of Steroid Biochemistry and Molecular Biology 61 185-192.

Somasundar P, Yu AK, Vona-Davis L \& McFadden DW 2003 Differential effects of leptin on cancer in vitro. Journal of Surgical Research 113 50-55.

Stattin P, Soderberg S, Biessy C, Lenner P, Hallmans G, Kaaks R \& Olsson T 2004 Plasma leptin and breast cancer risk: a prospective study in northern Sweden. Breast Cancer Research and Treatment 86 191-196.

Stephenson GD \& Rose DP 2003 Breast cancer and obesity: an update. Nutrition and Cancer 45 1-16.

Stull MA, Richert MM, Loladze AV \& Wood TL 2002 Requirement for IGF-I in epidermal growth factormediated cell cycle progression of mammary epithelial cells. Endocrinology 143 1872-1879.

Suganami T, Nishida J \& Ogawa Y 2005 A paracrine loop between adipocytes and macrophages aggravates inflammatory changes: role of free fatty acids and tumor necrosis factor alpha. Arteriosclerosis Thrombosis and Vascular Biology 25 2062-2068.

Suzuki T, Miki Y, Nakamura Y, Moriya T, Ito K, Ohuchi N \& Sasano H 2005 Sex steroid-producing enzymes in human breast cancer. Endocrine-Related Cancer 12 701-720.

Tanaka M, Nakaya S, Kumai T, Watanabe M, Tateishi T, Shimizu H \& Kobayashi S 2001 Effects of estrogen on serum leptin levels and leptin mRNA expression in adipose tissue in rats. Hormone Research 56 98-104.

Taniguchi T, Toi M, Inada K, Imazawa T, Yamamoto Y \& Tominaga T 1995 Serum concentrations of hepatocyte growth factor in breast cancer patients. Clinical Cancer Research 1 1031-1034. 
Tessitore L, Vizio B, Jenkins O, De Stefano I, Ritossa C, Argiles JM, Benedetto C \& Mussa A 2000 Leptin expression in colorectal and breast cancer patients. International Journal of Molecular Medicine 5 421-426.

Toi M, Taniguchi T, Ueno T, Asano M, Funata N, Sekiguchi K, Iwanari H \& Tominaga T 1998 Significance of circulating hepatocyte growth factor level as a prognostic indicator in primary breast cancer. Clinical Cancer Research 4 659-664.

Toniolo PG, Levitz M, Zeleniuch-Jacquotte A, Banerjee S, Koenig KL, Shore RE, Strax P \& Pasternack BS 1995 A prospective study of endogenous estrogens and breast cancer in postmenopausal women. Journal of the National Cancer Institute 87 190-197.

Van Belle E, Witzenbichler B, Chen D, Silver M, Chang L, Schwall R \& Isner JM 1998 Potentiated angiogenic effect of scatter factor/hepatocyte growth factor via induction of vascular endothelial growth factor: the case for paracrine amplification of angiogenesis. Circulation 97 381-390.

Wang B, Jenkins JR \& Trayhurn P 2005 Expression and secretion of inflammation-related adipokines by human adipocytes differentiated in culture: integrated response to TNF-alpha. American Journal of Physiology. Endocrinology and Metabolism 288 E731-E740.
Weisburg SP, McCann D, Desai M, Rosenbaum M, Leibel RL \& Ferrante AW, Jr 2003 Obesity is associated with macrophage accumulation in adipose tissue. Journal of Clinical Investigation 112 1796-1808.

Woo HY, Park H, Ki CS, Park YL \& Bae WG 2006 Relationships among serum leptin, leptin receptor gene polymorphisms, and breast cancer in Korea. Cancer Letters 237 137-142.

Yamashita T, Murakami T, Otani S, Kuwajima M \& Shima K 1998 Leptin receptor signal transduction: OBRa and $\mathrm{OBRb}$ of fa type. Biochemical and Biophysical Research Communications 246 752-759.

Zhao Y, Nichols JE, Valdez R, Mendelson CR \& Simpson ER 1996 Tumor necrosis factor-alpha stimulates aromatase gene expression in human adipose stromal cells through use of an activating protein- 1 binding site upstream of promoter 1.4. Molecular Endocrinology $\mathbf{1 0}$ 1350-1357.

Zhao T, Hou M, Xia M, Wang Q, Zhu H, Xiao Y, Tang Z, Ma J \& Ling W 2005 Globular adiponectin decreases leptininduced tumor necrosis factor-alpha expression by murine macrophages: Involvement of cAMP-PKA and MAPK pathways. Cellular Immunology 238 19-30. 